\author{
Andrzej JAKUBOWSKI \\ Uniwersytet Marii Curie-Skłodowskiej w Lublinie \\ andrzej.jakubowski@umcs.pl
}

\title{
PROBLEMY ROZWOJU GOSPODARCZEGO PAŃSTW NIEUZNAWANYCH NA PRZYKŁADZIE ABCHAZJI
}

ABSTRACT Problems of economic development of the unrecognised state - the case of Abkhazia

Since its inception as a result of the victorious war with Georgia, the de facto independent Abkhazia has been struggling with a deep economic crisis characterised by war damage, economic blockade and the lack of international recognition. The aim of this paper is to analyse the main problems and challenges of unrecognised states in the field of economic development on the example of the Republic of Abkhazia. The article summarises the economic consequences of the Georgian-Abkhazian conflict, characterises the economic development of Abkhazia in the post-war period and analyses the effects of the economic blockade as well as the economic effects of the support of the external patron (the Russian Federation).

Key words: Abkhazia, unrecognised states, economic development, economic blockade

Słowa kluczowe: Abchazja, państwa nieuznawane, rozwój gospodarczy, blokada ekonomiczna 


\section{WSTĘP}

W wyniku przegranej wojny (1992-1993) Gruzja utraciła faktyczną kontrolę nad terytorium Abchazji. Chociaż wydarzenie to nie miało konsekwencji prawnomiędzynarodowych, w jego wyniku doszło do powstania de facto niezależnej Republiki Abchazji, która przypieczętowała swoje aspiracje w 1999 r. poprzez proklamowanie niepodległości. Uzyskanie suwerenności - co prawda ograniczonej wyłącznie do wewnętrznego wymiaru - pozwoliło Abchazom na rozpoczęcie procesu państwowotwórczego oraz rozwój większości instytucji niezbędnych do funkcjonowania jako de facto państwa. Dynamiczny, choć ograniczający się w dużej mierze do sfery formalnej i symbolicznej rozwój nowo powstałej jednostki geopolitycznej wiązał się jednak z głębokim kryzysem na płaszczyźnie ekonomicznej, warunkowanym zniszczeniami wojennymi, ograniczeniami w handlu zagranicznym w związku z ustanowieniem blokady ekonomicznej oraz brakiem uznania międzynarodowego. Celem niniejszego artykułu jest analiza wyzwań i problemów rozwojowych państw nieuznawanych, dokonana na przykładzie Republiki Abchazji.

\section{EKONOMICZNE SKUTKI KONFLIKTU GRUZIŃSKO-ABCHASKIEGO}

Pod koniec lat 80. XX w., a więc w okresie poprzedzającym upadek systemu komunistycznego oraz wybuch wojny gruzińsko-abchaskiej, Abchazja była jednym z najbogatszych regionów Związku Radzieckiego. Subtropikalny klimat oraz korzystne położenie pomiędzy wschodnim wybrzeżem Morza Czarnego a pasmem Kaukazu Wysokiego sprzyjały rozwojowi wyspecjalizowanych gałęzi rolnictwa oraz turystyki. Produkcja rolna Abchazji, ukierunkowana niemal w całości na eksport, w dużej mierze zaspokajała potrzeby ZSRR na herbatę, tytoń, owoce cytrusowe, figi, oliwki, orzechy oraz winorośl $1^{1}$. Znaczne inwestycje w infrastrukturę turystyczną sprawiły, że kurorty Abchazji - obok Jałty, Soczi i Batumi - stały się jednymi z najpopularniejszych ośrodków wypoczynkowych w całym Związku Radzieckim. W okresie poprzedzającym jego upadek publiczny sektor turystyczny Abchazji, obejmujący ponad 125 hoteli i sanatoriów, mógł obsługiwać jednocześnie ponad 40 tys. turystów, natomiast w ciągu całego sezonu wypoczynkowego Abchazję - nazywaną powszechnie Czerwoną Riwierą odwiedzały nawet 2 miliony osób ${ }^{2}$. Duże znaczenie w abchaskiej gospodarce posiadał

T. Gomelauri, The Role of Economic Factors in Conflict Resolution in Georgia and the Caucasus, Central European University 2001/2002, s. 6-7, [online] http://pdc.ceu.hu/archive/00001807/, 12 III 2017; V. Chirikba, Abkhazia - Economic and Political Situation and Perspectives, 4 XI 1999, [online] http:// www.kapba.de/EconAndPolSit.html, 21 II 2017.

2 D. Bargandzhia, Economy. Traditional and Modern, [w:] The Abkhazians. A Handbook, red. G. Hewitt, London-New York 1998, s. 159-161. 
również przemysł lekki, przemysł wydobywczy, produkcja energii elektrycznej, a także rybołówstwo i leśnictwo ${ }^{3}$.

Rozpad Związku Radzieckiego i upadek systemu komunistycznego, jak również wiążąca się z tym utrata tradycyjnych rynków zbytu oraz odejście od systemu gospodarki planowanej ku gospodarce rynkowej przyniosły wymierne, negatywne skutki ekonomiczne. Obejmowały one przede wszystkim wyraźne zmniejszenie produkcji rolnej i przemysłowej, a także znaczny spadek ruchu turystycznego. Jednakże największy wpływ na załamanie się abchaskiego systemu gospodarczego na początku lat 90 . XX w. miała wojna gruzińsko-abchaska.

Zgodnie z obliczeniami Komisji Specjalnej, powołanej przez de facto władze Abchazji w celu oszacowania strat materialnych będących wynikiem działań wojennych, ich łączna wartość wyniosła ok. 11,3 mld dolarów (tab. 1). W 1994 r., tj. w pierwszym pełnym roku po zakończeniu działań wojennych, produkcja przemysłowa w Abchazji uległa zmniejszeniu o 93,2\% w stosunku do 1989 r., produkcja energii elektrycznej - o 60\%, natomiast produkcja rolna - o 75,3\% ${ }^{4}$. W wyniku działań zbrojnych wiele fabryk zostało zniszczonych, natomiast działalność tych, które przetrwały, została w dużej mierze ograniczona ze względu brak dostaw materiałów oraz brak funduszy na wynagrodzenia dla pracowników. Ogromne zniszczenia dotknęły również sektor rolny. Dewastacji uległo ok. 200 kołchozów, a także znaczne obszary upraw owoców cytrusowych oraz herbaty. Ogólna powierzchnia użytkowanych gruntów rolnych uległa zmniejszeniu o 17 tys. ha, natomiast powierzchnia sadów - o 13,5 tys. ha ${ }^{5}$. Ponadto znaczne obszary w południowo-wschodniej Abchazji zostały zaminowane, co skutecznie uniemożliwiło ich wykorzystywanie do celów produkcji rolnej. W związku z tym wartość eksportu owoców cytrusowych, herbaty oraz tytoniu z terytorium Abchazji wyniosła w $1994 \mathrm{r}$. niespełna 19\% poziomu z $1989 \mathrm{r}^{6}{ }^{6}$ Znaczne straty poniósł również sektor turystyczny. Całkowitemu zniszczeniu uległo ponad 90 spośród 125 ośrodków wypoczynkowych, hoteli i sanatoriów, natomiast 13 kolejnych wymagało remontu? Wszystko to sprawiło, że produkt krajowy brutto Abchazji - będący podstawowym i kompleksowym miernikiem wielkości gospodarki - wyniósł w 1994 r. 60,3 mln dolarów wobec $692,5 \mathrm{mln}$ dolarów w roku 1988 . Oznacza to, że przy uwzględnieniu poziomu inflacji wartość PKB Abchazji w 1994 r. stanowiła zaledwie 14\% poziomu z okresu przedwojennego ${ }^{8}$. Ponadto, zgodnie z danymi Programu Narodów Zjednoczonych ds. Rozwoju (UNDP), na skutek wojny gruzińsko-abchaskiej udział bezrobotnych w grupie osób w wieku produkcyjnym wzrósł do poziomu ok. 95\%, a nominalny dochód

3 T. Gomelauri, The Role of Economic Factors..., s. 6; V. Chirikba, Abkhazia - Economic and Political Situation...

$4 \quad$ V. Chirikba, Abkhazia - Economic and Political Situation...

5 Y. Gumba, T. Ketsba, Economic development prospects in Abkhazia and the concept of regional cooperation, [w:] From War Economies to Peace Economies in the South Caucasus, red. Ph. Champain, D. Klein, N. Mirimanova, London 2011, s. 162.

6 V. Chirikba, Abkhazia - Economic and Political Situation...

7 Y. Gumba, T. Ketsba, Economic development..., s. 166.

8 V. Chirikba, Abkhazia - Economic and Political Situation... 
rozporządzalny gospodarstw domowych na jednego mieszkańca zmniejszył się z poziomu ok. 800 dolarów w 1989 r. do ok. 120 dolarów w 1994 r. ${ }^{9}$

Tab. 1. Straty materialne Abchazji w wyniku wojny gruzińsko-abchaskiej*

\begin{tabular}{|c|c|}
\hline Rodzaj obiektu & $\begin{array}{l}\text { Wartość } \\
(\text { w mln \$) }\end{array}$ \\
\hline Zabytki architektury, ośrodki naukowo-badawcze, uniwersytety oraz szkoły średnie & 1400 \\
\hline System paliwowo-energetyczny & 2120 \\
\hline Infrastruktura transportowa & 2150 \\
\hline Budownictwo & 480 \\
\hline Rolnictwo & 610 \\
\hline Infrastruktura komunikacyjna i telewizyjna & 400 \\
\hline Własność prywatna & 150 \\
\hline Mieszkalnictwo i gospodarka komunalna & 80 \\
\hline Infrastruktura edukacyjna & 80 \\
\hline Przemysł & 250 \\
\hline Opieka zdrowotna & 300 \\
\hline Infrastruktura handlowa & 100 \\
\hline Usługi komunalne & 50 \\
\hline Urzędy państwowe oraz pozostała własność administracji publicznej & 400 \\
\hline Własność Spółdzielni Producenckiej „Absojuz” & 300 \\
\hline Pozostałe & 2440 \\
\hline Razem & 11300 \\
\hline $\begin{array}{l}\text { N cenach bieżących, według stanu na } 1 \text { stycznia } 1995 \mathrm{r} \text {. } \\
\text { ródło: Â.R. Fejzba, O.B. Šamba, Nacional'naâ èkonomika Abhazii: Učebnik dlâ } \\
\text { 51-53, za: Y. Gumba, T. Ketsba, Economic development prospects in Abkhazia an } \\
\text { l cooperation, [w: From War Economies to Peace Economies in the South Caucasus } \\
\text { Klein, N. Mirimanova, London 2011, s. } 161 \text {. }\end{array}$ & $\begin{array}{l}v \text {, Suhum } 2002 \text {, } \\
\text { concept of regio- } \\
\text { Ph. Champain, }\end{array}$ \\
\hline
\end{tabular}

Wojna gruzińsko-abchaska doprowadziła również do daleko idących przemian w sferze demograficznej. O ile w 1992 r. liczba ludności Abchaskiej Republiki Autonomicznej wynosiła 535,1 tys. osób, to w 1997 r. wyniosła zaledwie 146,0 tys., co oznacza prawie czterokrotny spadek (o 388,1 tys. osób) ${ }^{10}$. Choć w kolejnych latach doszło do stopniowego wzrostu potencjału ludnościowego, to jednak liczba ludności Abchazji

9 Report of UNDP-Led Feasibility Mission to Gali District and Adjacent Areas of Abkhazia, and Georgia, Bureau for Crisis Prevention and Recovery, April 2004, s. 10.

10 O vyâvlennyh faktah politiki ètničeskoj čistki/genocida, provodimoj na teritorii Abhazii, Gruziâ, $i$ neobhodimosti peredači vinovnyh lic $v$ ruki pravosudiâ $v$ sootvetsvii s meždunarodnymi principami nadležâîsego sudebnogo processa. Zaklî̀̌enie Gosudarstvennoj Komisii Gruzii po ustanovleniû faktov 
wciąż nie osiągnęła nawet połowy przedwojennego stanu i w 2016 r. wyniosła zaledwie $46 \%$ wartości z 1989 r. $^{11}$

\section{ROZWÓJ GOSPODARCZY W WARUNKACH BLOKADY EKONOMICZNEJ}

We wrześniu 1993 r., w odpowiedzi na wznowienie działań wojennych przez stronę abchaską oraz wyparcie z Abchazji formacji gruzińskich, władze Federacji Rosyjskiej zdecydowały się na wprowadzenie wobec tej separatystycznej republiki sankcji. Obejmowały one przerwanie dostaw energii elektrycznej i połączeń telefonicznych, zamknięcie granicy na rzece Psou, a także - począwszy od grudnia 1994 r. - zakaz przewozów towarowych oraz zakaz przekraczania granicy rosyjskiej przez posiadaczy paszportów radzieckich zameldowanych na terenie byłej Abchaskiej ASRR ${ }^{12}$.

Izolacja stała się również głównym elementem polityki Gruzji wobec Abchazji, której założenia były stopniowo rozwijane w 1994 oraz 1995 r. Jej ostateczny kształt został usankcjonowany 19 stycznia 1996 r. wraz z wprowadzonym przez państwa WNP embargiem ${ }^{13}$. Podpisana tego dnia w Moskwie „Decyzja Rady Szefów Państw - członków WNP o środkach na rzecz uregulowania konfliktu w Abchazji" uprawomocniła niemal całkowitą izolację Abchazji od świata zewnętrznego. Dokument ten, zobowiązujący jego sygnatariuszy do powstrzymania się od nawiązywania jakiejkolwiek współpracy z władzami Abchazji, w tym przede wszystkim na płaszczyźnie politycznej i militarnej, wprowadził również szereg ograniczeń o charakterze gospodarczym. Na jego mocy zakazane zostały transakcje w zakresie handlu towarami i usługami, transfery środków finansowych oraz operacje transportowe ${ }^{14}$. Handel z Abchazją został ograniczony jedynie do artykułów żywnościowych, leków, paliw oraz artykułów gospodarstwa domowego. Import pozostałych towarów wymagał licencjonowania przez Gruzję ${ }^{15}$.

politiki ètničeskoj čistki-genocida, provodimoj votnošenii gruzinskogo naseleniâ v Abhazii, Gruziâ, i peredači materialov v Meždunarodnyj Tribunal, Moskva 1997.

11 Abhaziâ v cifrah 2015, Suhumi 2016, s. 15.

12 N. Akaba, I. Gicba, Izolâciâ/deizolâciâ Abhazii i transformaciâ gruzino-abhazskogo konflikta. Istoriko-političeskij analiz, [w:] Deizolaciâ Abhazii, International Alert 2011, s. 8, [online] http://legacy. international-alert.org/sites/default/files/publications/201104DeisolationAbkhaziaRU.pdf, 22 III 2017; Postanovlenie Pravitel'stva Rossijskoj Federacii ot 19 dekabrâ 1994 g. N 1396 o merah po vremennomu ograničeniû peresečeniâ Gosudarstvennoj granicy Rossijskoj Federacii s Azerbajdžanskoj Respublikoj i Respublikoj Gruziâ, [online] http://pravo.gov.ru/proxy/ips/?doc_itself=\&backlink=1\&\&nd $=102033244 \& \&$ page $=1 \&$ rdk=9, 21 II 2017.

13 A. Gegešidze, Vvedenie, [w:] Deizolaciâ Abhazii, s. 31.

14 Rešenie Soveta glav gosudarstv SNG o merah po uregulirovaniû konflikta v Abhazii, Gruziâ, Sovet Bezopasnosti, dok. 258, 31 ânvarâ 1996 g., A/51/62 - S/1996/74, [w:] Konflikty v Abhazii i Ûžnoj Osetii. Dokumenty 1989-2006 gg., red. M. Volhonskij, V. Zaharov, N. Silaev, Moskva 1997, s. 357-358.

15 S. Closson, Georgia's Secessionist De Facto States: From Frozen to Boiling, „Caucasus Analytical Digest” 2008, nr 40, s. 3, [online] http://www.css.ethz.ch/content/dam/ethz/special-interest/gess/cis/ center-for-securities-studies/pdfs/RAD-40-2-5.pdf, 16 III 2017. 
Jednocześnie państwa członkowskie WNP zwróciły się do Rady Bezpieczeństwa ONZ z apelem o wyrażenie poparcia dla działań Wspólnoty wobec Abchazji oraz o rekomendowanie wszystkim członkom ONZ przyłączenie się do realizacji postanowień zawartych w dokumencie ${ }^{16}$. Tego dnia prezydent Gruzji Eduard Szewardnadze podpisał również dekret ustanawiający blokadę morską. Na jego mocy port morski Suchumi, pozostałe porty oraz cały obszar wód wewnętrznych na terytorium Abchazji zostały zamknięte dla transportu międzynarodowego, z wyjątkiem dostaw pomocy humanitarnej, dopuszczalnej jednak wyłącznie po uprzedniej kontroli towaru, przeprowadzonej przez służby celne, a także uzyskaniu zgody odpowiednich organów administracji Gruzji ${ }^{17}$. Oprócz wymienionych powyżej dokumentów zakres i charakter izolacji Abchazji był również determinowany treścią Rezolucji Rady Bezpieczeństwa ONZ nr 876 z 1993 r., wzywającej państwa członkowskie do nieudzielania pomocy stronie abchaskiej, z wyłączeniem pomocy humanitarnej, a w szczególności do uniemożliwienia zaopatrywania jej w broń i amunicję ${ }^{18}$. Duże znaczenie miały również decyzje władz Gruzji o niewystępowaniu do Międzynarodowej Organizacji Lotnictwa Cywilnego o przyznanie tzw. międzynarodowego kodu lotniska dla portu lotniczego w Suchumi (co w praktyce oznaczało jego wyłączenie z obsługi lotów międzynarodowych), wprowadzeniu blokady tzw. Transkaukaskiego Szlaku Transportowego na odcinku przebiegającym przez terytorium Abchazji (obejmującego zarówno magistralę kolejową, jak i drogową), a także niemal całkowitej rezygnacji ze współpracy gospodarczej ze stroną abchaską, z wyjątkiem wspólnej eksploatacji elektrowni wodnej na rzece Enguri ${ }^{19}$.

Na skutek blokady ekonomicznej wartość obrotów w handlu zagranicznym Abchazji w pierwszych latach powojennych pozostawała na bardzo niskim poziomie i charakteryzowała się wyraźnym ujemnym saldem (tab. 2). Ograniczona była również jego struktura przestrzenna - przykładowo w 1997 r. ok. 62\% importowanych towarów sprowadzono z Turcji, natomiast $12 \%$ z Rosji. Kraje te były również głównymi odbiorcami towarów abchaskich - do Rosji trafiło 54\%, do Turcji zaś 45\% abchaskiego eksportu. W obliczu poważnych ograniczeń administracyjnych, finansowych i technicznych większość transakcji handlowych miała charakter operacji jednorazowych, częstokroć realizowanych na zasadzie wymiany barterowej. Ze względu na obowiązujące restrykcje w okresie tym nie było możliwości realizacji regularnych transakcji handlowych, a dostęp do mechanizmów finansowania był bardzo ograniczony ${ }^{20}$.

16 N. Akaba, I. Gicba, Izolâciâ/deizolâciâ Abhazii..., s. 9.

17 Ukaz Prezidenta Gruzii o pograničnom i tamožennom režimah na učastke gosudarstvennoj granicy Rossii Gruzii v predelah akvatorii Abhazii (Gruziâ), v Subumskom morskom portu, portopunktah i morskoj akvatorii, dok. 44, [w:] Konflikty v Abhazii i Û̌noj Osetii..., s. 78.

18 Resolution 876 (1993) Adopted by the Security Council at its 3295th meeting, on 19 October 1993, [online] http://www.refworld.org/docid/3b00f1-5a50.html, 12 IV 2017.

19 A. Gegeshidze, The Isolation of Abkhazia. a Failed Policy or an Opportunity, [w:] Accord. Powers of persuasion. Incentives, sanctions and conditionality in peacemaking, red. A. Griffiths, C. Barnes, London 2008, s. 69, [online] http://www.c-r.org/sites/cr.org/files/19_Powers\%20of\%20persuasion_2008_ ENG_F.pdf, 21 III 2017; A. Gegešidze, Vvedenie..., s. 32.

20 UNDP/World Bank Needs Assessment. Mission to Abkhazia, Georgia, February/March 1998, s. 4, [online] http://www.berntbernander.com/PDF/reports/Abkhasia.pdf, 21 III 2017. 
POLITEJA 4(55)/2018 Problemy rozwoju gospodarczego państw...

Tab. 2. Handel zagraniczny Abchazji w latach 1995-2015

\begin{tabular}{|c|c|c|c|c|}
\hline \multirow[t]{2}{*}{ Rok } & $\begin{array}{l}\text { Obroty handlu } \\
\text { zagranicznego }\end{array}$ & Eksport & Import & Saldo \\
\hline & \multicolumn{4}{|c|}{$\mathrm{w} m \ln \$$} \\
\hline 1995 & 7,6 & 2,8 & 4,8 & -2 \\
\hline 1996 & 17,6 & 6,0 & 11,6 & $-5,6$ \\
\hline 1997 & 20,0 & 6,0 & 14,0 & -8 \\
\hline 1998 & 9,7 & 4,0 & 5,7 & $-1,7$ \\
\hline 1999 & 17,6 & 6,3 & 11,3 & -5 \\
\hline 2000 & b.d. & b.d. & b.d. & b.d. \\
\hline 2001 & b.d. & b.d. & b.d. & b.d. \\
\hline 2002 & 47,7 & 16,6 & 31,0 & $-14,4$ \\
\hline 2003 & 56,7 & 17,3 & 39,3 & $-22,0$ \\
\hline 2004 & 75,7 & 54,7 & 21,0 & $-33,7$ \\
\hline 2005 & 118,1 & 27,7 & 90,4 & $-62,8$ \\
\hline 2006 & 143,3 & 23,1 & 120,3 & $-97,2$ \\
\hline 2007 & 183,6 & 21,4 & 162,1 & $-140,7$ \\
\hline 2008 & 285,6 & 35,8 & 249,8 & $-213,9$ \\
\hline 2009 & 268,8 & 34,3 & 234,4 & $-200,1$ \\
\hline 2010 & 413,2 & 70,1 & 343,1 & $-273,0$ \\
\hline 2011 & 532,4 & 66,1 & 466,3 & $-400,3$ \\
\hline 2012 & 531,5 & 81,6 & 449,9 & $-368,3$ \\
\hline 2013 & 541,4 & 81,1 & 460,3 & $-379,1$ \\
\hline 2014 & 423,4 & 62,1 & 361,3 & $-299,1$ \\
\hline 2015 & 916,5 & 262,3 & 654,2 & $-392,0$ \\
\hline
\end{tabular}

Źródło: obliczenia własne na podstawie: UNDP/World Bank Needs Assessment...; Abhaziâ v cifrah 2011, Suhumi 2012, s. 122; Abhaziâ v cifrah 2014, Suhumi 2015, s. 135; Abhaziâ v cifrah 2015..., s. 131. Przeliczeń dokonano na podstawie oficjalnego kursu rubla w stosunku do dolara amerykańskiego według danych Banku Światowego, [online] http://data.worldbank.org/indicator/PA.NUS.FCRF, 1 III 2017.

W sytuacjach, w których gospodarka wolnorynkowa nie może się rozwijać w sposób swobodny, pojawiająca się nisza zostaje wypełniona przez tzw. czarny rynek ${ }^{21}$. W 1999 r. J. Koèn pisat: Wiele osób dziatających na czarnym rynku, lokalnych monopolistów, pracowników Straży Granicznej oraz milicjantów czerpie korzyści z nieuregulowanej gospodarki i nie jest zainteresowanych zakończeniem konfliktu. Stosunki gospodarcze

${ }^{21} \quad$ N. Akaba, I. Gicba, Izolâciâ/deizolâciâ Abhazii..., s. 9-10. 
i etniczne biznesmenów iprzestępców zlewają się, gdy chodzi o osiaganie zysków [...]. Ograniczenia $w$ handlu sa przyczyna znacznych problemów w Abchazji, lecz zamiast zmuszać do ustępstw politycznych, izolacja powoduje powstanie tzw. mentalności oblężenia, zmniejszającej sktonność do kompromisu. To również przyczynia się do rozwoju gospodarki przestępczej oraz gospodarki sprzeciwu narodowego, podważajac perspektywy umocnienia siępraworzadności $i^{22}$. Wprowadzone przez państwa WNP embargo było więc dość powszechnie łamane. Od momentu jego wprowadzenia, na terenie Abchazji zdołał się rozwinąć znaczny nielegalny handel orzechami, cytrusami, paliwem, alkoholem, papierosami, złomem, węglem oraz drewnem, realizowany zarówno przez graniczną rzekę Psou (z Rosją), jak i Enguri (z Gruzją). Ponadto rosyjskie, tureckie, bułgarskie oraz rumuńskie statki systematycznie łamały obowiązujące restrykcje bez zgody ze strony Tbilisi ${ }^{23}$. Według niektórych szacunków pod koniec lat $90 . \mathrm{XX}$ w. porty morskie Abchazji obsługiwały ok. 60-70\% całości nielegalnych operacji w handlu zagranicznym tej nieuznawanej republiki ${ }^{24}$. Niejednokrotnie jednostki działające w szarej strefie powiązane były z najwyższymi urzędnikami państwowymi, w tym z rodziną pierwszego de facto prezydenta Abchazji Władisława Ardzinby. Wymierne korzyści z przemytu czerpały przy tym nie tylko współpracujące ze sobą abchaskie i gruzińskie organizacje przestępcze, lecz także przedstawiciele abchaskich i gruzińskich służb mundurowych, a nawet rosyjskich sił pokojowych stacjonujących $\mathrm{w}$ regionie ${ }^{25}$. Podkreślenia wymaga również rola, jaką w przypadku powojennej, izolowanej gospodarki abchaskiej odgrywała produkcja i sprzedaż narkotyków, nielegalny handel bronią, pranie brudnych pieniędzy, handel ludźmi, a nawet przemyt materiałów radioaktywnych ${ }^{26}$.

Załamanie systemu produkcji przemysłowej i rolniczej, restrykcje w handlu zagranicznym, a także rozkwit nielegalnej działalności gospodarczej przełożyły się na katastrofalną sytuację finansów publicznych Abchazji (tab. 3). Utrzymujące się na skrajnie niskim poziomie wpływy do budżetu - będące konsekwencją zarówno trudnej,

22 D. Koèn, Ėkonomičeskie aspekty. Stimul ili prepâtstvie?, [w:] Problemy suvereniteta. Gruzino-abhazskij process mirnogo uregulirovaniâ, red. tenże, London 1999, s. 49, [online] http://www.c-r.org/sites/c-r. org/files/Accord7_RussianFull.pdf, 1 III 2017, tłum. własne.

23 Abkhazia: Ways Forward, International Crisis Group Europe Report $N^{\circ} 179$ - 18 January 2007, s. 30, [online] https://www.crisisgroup.org/europe-central-asia/caucasus/abkhazia-georgia/abkhaziaways-forward, 12 IV 2017.

24 D. Chkhartishvili, R. Gotsiridze, B. Kitsmarishvili, Georgia. Conflict Regions and Economies, [w:] From War Economies to Peace Economies in the South Caucasus, red. Ph. Champain, D. Klein, N. Mirimanova, London 2011, s. 140.

25 Tamże, s. 120.

26 A. Kukhianidze, A. Kupatadze, R. Gotsiridze, Smuggling through Abkhazia and Tskhinvali Region, Tbilisi 2004, s. 31-36; C.M. Traughber, Terrorism and Arms, Drug, and Human Trafficking in Georgia, „The Quarterly Journal” 2007, s. 52-53, [online] http://connections-qj.org/system/files/06.1.04_ traughber.pdf, 21 IV 2017; M. Tokmazishvili, Money Laundering and Money Corporation Relations in Abkhazia, [online] http://www.conflicts.rem33.com/images/Georgia/crim_abkh_tokmaz. pdf, 1 IV 2017; G.E. Curtis, Involvement of Russian Organized Crime Syndicates, Criminal Elements in the Russian Military, and Regional Terrorist Groups in Narcotics Trafficking in Central Asia, The Caucasus and Chechnya, Washington 2002, s. 3-7, [online] https://www.loc.gov/rr/frd/pdf-files/ RussianOrgCrime.pdf, 12 IV 2017. 
powojennej sytuacji gospodarczej, jak i znikomej skuteczności systemu podatkowego - sprawiły, że podstawowym ograniczeniem w działalności de facto władz Abchazji stał się brak zasobów finansowych. W obliczu braku uznania międzynarodowego, izolacji zewnętrznej oraz przy praktycznie nieistniejącym systemie bankowym deficyt w finansach publicznych Abchazji nie mógł zostać pokryty poprzez zaciąganie pożyczek, bądź też przez wykorzystanie rezerw. Jedynym rozwiązaniem było redukowanie wydatków, co w największym stopniu dotyczyło sfery tzw. usług publicznych (z wyjątkiem wydatków na obronność i bezpieczeństwo). Borykając się z niewystarczającymi zasobami budżetowymi, de facto władze Abchazji ograniczały się do realizacji jedynie najbardziej podstawowych funkcji państwa, obejmujących utrzymanie porządku oraz bezpieczeństwa publicznego, natomiast wydatki na inwestycje i usługi publiczne były utrzymywane na możliwie minimalnym poziomie ${ }^{27}$. W związku z tym opieka zdrowotna oraz system edukacji mogły przetrwać jedynie dzięki pomocy zagranicznych organizacji humanitarnych ${ }^{28}$ oraz opłatom pobieranym bezpośrednio od beneficjentów ${ }^{29}$.

Skutki izolacji okazały się bardzo uciążliwe zarówno dla abchaskiej gospodarki, jak i dla miejscowej ludności. Według szacunków międzynarodowej organizacji Lekarze bez Granic w 2002 r. ok. 18 tys. osób - a więc niemal jedna dziesiąta mieszkańców Abchazji - żyło w skrajnym ubóstwie i potrzebowało natychmiastowej pomocy humanitarnej ${ }^{30}$. Zgodnie z wynikami badań przeprowadzonych wśród mieszkańców Abchazji w 1996 r. przez A. Kryłowa z Rosyjskiej Akademii Nauk, podstawowym źródłem utrzymania ludności było prowadzenie gospodarstwa rolnego na własny użytek (28\% respondentów), praca najemna (zaledwie $15 \%$ respondentów) oraz prowadzenie prostej działalności handlowej zgodnie z formułą „kup-sprzedaj” (5\%). Pozostali respondenci utrzymywali się z prac dorywczych, a także dzięki pomocy bliskich oraz organizacji humanitarnych. Jednocześnie za główną przyczynę trudnej sytuacji życiowej uznawali oni blokadę Abchazji (49\% respondentów), kryzys ekonomiczny i bezrobocie (33\%), a także nieuregulowany status polityczny Abchazji $(13 \%)^{31}$.

\section{UNDP/World Bank Needs Assessment..., s. 6.}

28 Pod koniec lat 90. XX w. na terenie Abchazji działało kilka organizacji humanitarnych, m.in. United Nations High Commisioner for Refugees (UNHCR), Fundusz Narodów Zjednoczonych na rzecz Dzieci (UNICEF), UNDP, Medicins sans Frontières, Acción contra la Hambre, International Committee of the Red Cross (ICRC), HALO Trust oraz Departament Pomocy Humanitarnej Unii Europejskiej ECHO. Ich działalność koncentrowała się na pomocy żywnościowej, odbudowie infrastruktury komunalnej w zakresie dostaw wody i energii, odbudowie szkół oraz obiektów służby zdrowia, budowie schronisk dla osób szczególnie potrzebujących, rozminowywaniu, a także wsparciu dla powracających uchodźców. OCHA Georgia. Abkhazia Briefing Note, UNDP 2004, [online] http:// reliefweb.int/report/georgia/ocha-georgia-abkhazia-briefing-note-jan-2004, 1 III 2017.

29 UNDP/World Bank Needs Assessment..., s. 5-6.

30 Abkhazia. Old and Frail In the Shadow of the Embargo. Report, Médecins Sans Frontiérs, December 2002, s. 2, [online] https://www.msf.fr/sites/default/files/7083212723e4147d15960a1aa0b48d44. pdf., 1 IV 2017.

31 A. Krylov, Religia i tradicii Abhazov (po materialam polevyh issledovanij 1994-2000 gg.), Moskva 2001, s. 36-38. 
Tab. 3. Budżet Abchazji w latach 1995-2015 (w mln dolarów)

\begin{tabular}{|c|c|c|c|}
\hline \multirow[t]{2}{*}{ Rok } & Dochody & Wydatki & $\begin{array}{c}\text { Nadwyżka/ } \\
\text { deficyt }\end{array}$ \\
\hline & \multicolumn{3}{|c|}{$\mathrm{w} m \ln \$$} \\
\hline 1995 & 3,3 & 4,0 & $-0,7$ \\
\hline 1996 & 4,9 & 5,3 & $-0,4$ \\
\hline 1997 & 5,6 & 5,8 & $-0,2$ \\
\hline 1998 & 6,1 & 6,0 & 0,1 \\
\hline 1999 & 6,2 & 6,0 & 0,2 \\
\hline 2000 & 6,3 & 5,7 & 0,6 \\
\hline 2001 & 7,2 & 7,4 & $-0,2$ \\
\hline 2002 & 7,2 & 7,7 & $-0,5$ \\
\hline 2003 & 9,2 & 8,5 & 0,7 \\
\hline 2004 & 18,5 & 18,3 & 0,1 \\
\hline 2005 & 18,5 & 18,3 & 0,1 \\
\hline 2006 & 25,1 & 24,6 & 0,5 \\
\hline 2007 & 40,2 & 41,3 & -1 \\
\hline 2008 & 56,1 & 55,4 & 0,6 \\
\hline 2009 & 71,5 & 73,3 & $-1,7$ \\
\hline 2010 & 133,8 & 130,8 & 3 \\
\hline 2011 & 154 & 148,1 & 5,9 \\
\hline 2012 & 308,9 & 318,8 & $-9,9$ \\
\hline 2013 & 252,6 & 255,6 & -3 \\
\hline 2014 & 178,1 & 180,2 & $-2,1$ \\
\hline 2015 & 94,6 & 100,2 & 5,6 \\
\hline
\end{tabular}

Źródło: obliczenia własne na podstawie: UNDP/World Bank Needs Assessment..., s. 5; D. Chkhartishvili, R. Gotsiridze, B. Kitsmarishvili, Georgia. Conflict Regions..., s. 125; Abhaziâ v cifrah 2011..., s. 98; Abhaziâ $v$ cifrah 2014..., s. 112; Abhaziâ v cifrah 2015..., s. 12. Przeliczeń dokonano na podstawie oficjalnego kursu rubla w stosunku do dolara amerykańskiego według danych Banku Światowego, [online] http://data. worldbank.org/indicator/PA.NUS.FCRF, 1 III 2017.

Izolacja Abchazji oraz wynikający z niej brak wsparcia zewnętrznego - przede wszystkim dostępności kapitału i kredytów - jedynie pogłębiły i utrwaliły negatywne skutki wojny gruzińsko-abchaskiej na płaszczyźnie społeczno-ekonomicznej. Według danych prezentowanych przez W. Czirikbę, straty gospodarcze spowodowane wprowadzeniem blokady ekonomicznej wyniosły w ciągu pierwszych trzech lat obowiązywania ok. $500 \mathrm{mln}$ dolarów, a więc niewiele mniej od PKB Abchazji w okresie 
poprzedzającym wybuch konfliktu ${ }^{32}$. W wyniku nałożonej blokady gospodarka Abchazji nie była w stanie podjąć wysiłku związanego z odbudową i rozwojem, pogrążając się w długotrwałym kryzysie gospodarczym.

\section{ROZWÓJ GOSPODARCZY W WARUNKACH PATRONATU ROSJI}

Abchazja pozostawała niemal w pełni izolowana do 1999 r., kiedy to reżim sankcji pomimo jego ciągłego formalnego obowiązywania - zaczął ulegać stopniowemu łagodzeniu przez stronę rosyjską. W pierwszej kolejności uproszczone zostały zasady przekraczania de facto granicy rosyjsko-abchaskiej. W 2002 r. przywrócone zostało połączenie kolejowe pomiędzy Suchumi i Soczi ${ }^{33}$. Jednocześnie Rosja wstrzymała blokadę portów abchaskich, do których zaczęły zawijać statki zagranicznych armatorów. Dzięki temu z każdym rokiem do Abchazji zaczęła przybywać coraz większa liczba rosyjskich turystów, wyraźnie zaczęły wzrastać również obroty w handlu zagranicznym (tab. 2). W 2000 r. Federacja Rosyjska zaczęła wydawać paszporty obywatelom de facto Abchazji. Początkowo zjawisko to miało ograniczony zasięg, jednakże uchwalona w kwietniu 2002 r. przez rosyjską Dumę Państwową nowa ustawa o obywatelstwie pozwoliła już na masowe przyznawanie obywatelstwa Federacji Rosyjskiej oraz wydawanie paszportów mieszkańcom Abchazji ${ }^{34}$, o co w lipcu 2002 r. zawnioskowało ponad 150 tys. rezydentów tej nieuznawanej republiki35. Do końca sierpnia 2005 r. ok. 84\% jej mieszkańców posiadało już paszporty rosyjskie, dzięki czemu uzyskali oni możliwość podróżowania nie tylko poza granice Abchazji, ale i Rosji ${ }^{36}$. Co więcej, części z tych osób Fundusz Emerytalny Federacji Rosyjskiej zaczął wypłacać świadczenia. W 2005 r. ponad 26 tys. osób, tj. ok. 70\% uprawnionych, pobierało emerytury rosyjskie ${ }^{37}$.

Oficjalnym powodem stopniowego odchodzenia od reżimu sankcji przez stronę rosyjską była kwestia niskiej efektywności tego instrumentu, choć oczywiście rzeczywistych przyczyn tego przewartościowania w polityce Rosji należy upatrywać w pogorszeniu się jej relacji z Gruzją. Z kolei władze Gruzji, pomimo tego, że zdawały sobie sprawę z braku skuteczności sankcji, obstawały konsekwentnie przy utrzymaniu blokady aż do momentu przywrócenia pełnej integralności terytorialnej państwa oraz powrotu

\footnotetext{
32 V. Chirikba, Abkhazia - Economic and Political Situation...

33 A. Gegešidze, Vvedenie..., s. 33.

34 Federal’nyj zakon o graždanstve Rossijskoj Federacii ot 31 maâ 2002 g., H62-63, [online] http://www. mid.ru/-dks.nsf/mnsdoc/04.03.02.02, 18 IV 2017.

35 T. Trier, H. Lohm, D. Szakonyi, Under Siege. Inter-Ethnic Relations in Abkhazia, London 2010, s. 8.

36 N.M. Ezrow, People without Passports - Exploring the Consequences of Different Types of Restricted Mobility, s. 18, [online] http://citation.allacademic.com/meta/p_mla_apa_research_citation/-2/6/8/4/3/ pages268437/p268437-1.php, 1 IV 2017; I.C. Svendsen, Prospects for Return of Internally Displaced Persons (IDPs) to Abkhazia in Georgia, Tbilisi 2005, s. 19, [online] http://www.internal-displacement. org//\$file/Abkhazia+NRC+Nov+05.pdf, 15 IV 2017.

37 V Abhazii zaregistrirovany 26 tysâč rossijskih pensionerov, „Naselenie i obŝestvo” 2005, nr 197-198, [online] http://www.demoscope.ru/weekly/2005/0197/panorm01.php\#1, 1 IV 2017.
} 
uchodźców do miejsc zamieszkania na całym terytorium Abchazji. Jak zauważył A. Gegeszidze, już na przełomie 2002 i 2003 r. polityka izolacji Abchazji utraciła jednak swój pierwotny charakter narzędzia presji na społeczeństwo abchaskie w wymiarze społeczno-ekonomicznym. Według niego od tego momentu nabrała ona wręcz kontrproduktywnego charakteru wobec kwestii uregulowania konfliktu gruzińsko-abchaskiego i jedynie pogarszała pozycję Gruzji. Wskazał on jednocześnie na trzy świadczące o tym przesłanki. Po pierwsze, pomijając fakt, iż polityka izolacji była kontynuowana również przez państwa Zachodu, z perspektywy elit abchaskich główną barierą na drodze do budowania relacji ze światem zewnętrznym pozostawała Gruzja. W sytuacji niemal zupełnego braku zaufania pomiędzy stronami konfliktu jeszcze bardziej oddalało je to od możliwego kompromisu, a być może uczyniło go wręcz nierealnym. Po drugie, w percepcji abchaskiej Rosja zaczęła wyrastać na jej jedynego sojusznika i opiekuna ${ }^{38}$. Jak bowiem zauważają N. Akaba oraz I. Gicba: O ile w czasie blokady panowaty nastroje zarówno antygruzinskie, jak i antyrosyjskie, to wraz z tagodzeniem sankcji przez stronę rosyjska, stosunek do niej zacząt się zauważalnie zmieniać na pozytywny ${ }^{39}$. Wykorzystując tę sposobność, Rosja zaczęła zwiększać kontrolę nad sytuacją wewnętrzną w Abchazji, uzyskując nad nią niemal pełną dominację. Wreszcie po trzecie, Abchazowie, zabezpieczywszy się z pomocą Rosji na wypadek agresji ze strony Gruzji, przestali ją traktować jako źródło zagrożenia, ale też przestali uznawać ewentualną współpracę z byłą republiką macierzystą za potencjalny czynnik rozwoju ${ }^{40}$. Paradoksalnie, realizacja polityki izolacji nie przyniosła więc osiągnięcia żadnego z zakładanych przez Gruzję celów, a jedynie pogłębiała nieufność Abchazów i jeszcze bardziej oddaliła od siebie strony konfliktu. Z kolei stopniowe łagodzenie reżimu sankcji przez Federację Rosyjską doprowadziło do niemal pełnego uzależnienia od niej gospodarki Abchazji.

Poprawa sytuacji społeczno-gospodarczej Abchazji zaczęła być dostrzegana dopiero w drugiej połowie pierwszej dekady XXI w., co wiązało się z wejściem na rynek abchaski rosyjskich inwestorów, napływem turystów z Rosji, rozwojem handlu rosyjsko-abchaskiego, a także - począwszy od 2008 r. - bezpośredniej pomocy finansowej w postaci subsydiowania budżetu ${ }^{41}$. W 2009 r. 60\% budżetu Abchazji (ok. 65,5 mln dol.) stanowiło bezpośrednie wsparcie ze strony Rosji ${ }^{42}$. Jednakże prawdziwy przełom w sferze finansów publicznych Abchazji przyniosło wejście w życie wypracowanego na podstawie Umowy o przyjaźni, współpracy oraz wzajemnej pomocy pomiędzy Federacją Rosyjską a Republiką Abchazji z dnia 17 września 2008 r. ${ }^{43}$ (a więc zawartego już

\footnotetext{
38 A. Gegešidze, Vvedenie..., s. 33.

39 N. Akaba, I. Gicba, Izolâciâ/deizolâciâ Abhazii..., s. 8-10.

40 A. Gegešidze, Vvedenie..., s. 33.

41 Szerzej: T. Trier, H. Lohm, D. Szakonyi, Under Siege..., s. 108-110.

42 Abkhazia: Deepening Dependence, International Crisis Group Europe Report $N^{\circ} 202-26$ February 2010 , s. 5, [online] https://www.crisisgroup.org/europe-central-asia/caucasus/georgia/abkhaziadeepening-dependence, 12 IV 2017.

43 Dogovor o družbe, sotrudničestve i vzaimnoj pomoŝi meždu Rossijskoj Federaciej i Respublikoj Abhaziâ ot 17 sentâbrâ 2008 g., [online] http://archive.kremlin.ru/text/docs/2008/09/206583.shtml, 4 IV 2017.
} 
po uznaniu przez Rosję niepodległości Abchazji) tzw. „Kompleksowego planu działań na rzecz rozwoju społeczno-ekonomicznego Republiki Abchazji na lata 2010-2012". Przewidywał on rosyjskie wsparcie finansowe na łączną kwotę 10,9 mld rubli, tj. ok. $358,9 \mathrm{mln}$ dolarów. Pomoc ta została przeznaczona na budowę i remonty infrastruktury transportowej i logistycznej, rozwój sektora turystyczno-rekreacyjnego, a także odbudowę obiektów infrastruktury społeczno-kulturalnej ${ }^{44}$. Inwestycje te objęły jednak niemal wyłącznie północno-zachodnią, a więc graniczącą z Rosją część nieuznawanej republiki. Dzięki pomocy rosyjskiej w ciągu zaledwie czterech lat (2008-2012) wielkość budżetu Abchazji wzrosła niemal sześciokrotnie (tab. 3).

Rosja stała się przy tym praktycznie jedynym inwestorem zagranicznym (99\% realizowanych inwestycji $)^{45}$ oraz najważniejszym partnerem handlowym Abchazji. Od momentu przyjęcia dekretu prezydenta Federacji Rosyjskiej o uznaniu niepodległości Abchazji wartość obrotów handlowych z tą de facto republiką wzrosła ponad dwukrotnie, natomiast w porównaniu do roku 2005 - niemal czterokrotnie (tab. 2). W dniu 10 grudnia 2013 r. Duma Federacji Rosyjskiej ratyfikowała Porozumienie z Abchazją o handlu bezcłowym. Na jego mocy ustanowiony został reżim bezcłowego importu towarów z zaledwie kilkoma wyjątkami ${ }^{46}$. Według danych za pierwsze półrocze $2015 \mathrm{r}$. na Federację Rosyjską przypadało 65\% obrotów handlowych, w tym 58\% eksportu oraz $68 \%$ importu $^{47}$. Widoczne jest więc niezwykle silne uzależnienie gospodarki Abchazji od Rosji, będącej nie tylko podstawowym odbiorcą towarów abchaskich, ale również głównym dostawcą, przede wszystkim paliw oraz produktów przemysłowych.

Od momentu uznania przez Rosję niepodległości, Abchazja zgodziła się na przekazanie jej wiele atrybutów własnej suwerenności, w tym na transfer strategicznych przywilejów ekonomicznych i transportowych oraz przyjęcie kilku rosyjskich standardów technicznych i handlowych. W maju 2009 r. minister gospodarki Abchazji zawarł z rosyjskim państwowym potentatem naftowym Rosnieft umowę, która daje mu prawo wykorzystywania abchaskiego szelfu kontynentalnego. Abchazja zgodziła się też na przekazanie abchaskich linii kolejowych oraz portu lotniczego w Suchumi pod zarząd rosyjski na okres 10 lat, w zamian za inwestycje oraz udzielenie pożyczki. W październiku $2009 \mathrm{r}$. zawarto kolejne porozumienie, na mocy którego w ręce Rosjan przeszła odpowiedzialność za kontrolę ruchu powietrznego i nawigację lotniczą w Abchazji. Abchazja przyjęła również rosyjskie prefiksy telefoniczne, a rosyjski rubel stał się oficjalną abchaską walutą, zastępując dotychczasowego apsara ${ }^{48}$. Wiele kontrowersji wywołują pojawiające się

44 Otčet o rezul'tatah kontrol'nogo meropriâtiâ «Proverka celevogo i èffektivnogo ispol'zovaniâ sredstv federal'nogo bûdžeta, napravlennyh na okazanie finansovoj pomoŝi Respublike Abhaziâ v celâh social'no-èkonomičeskogo razvitiâ i osûsestvleniâ bûdžetnyh investicij», [online] http://www.ach.gov.ru/user files/bulletins/2012-07-06-buleten_doc_files-fl-2247.pdf, 14 IV 2017.

45 Abkhazia: Deepening Dependence..., s. 6.

46 Gosduma RF odobrila soglašeniâ o bespošlinnoj torgovle s abhaziej i ûžnoj osetiej, „Kavkazskij Uzel” 2013, 10 X, [online] https://www.kavkaz-uzel.ru/articles/234889/, 13 IV 2017.

47 Dane Państwowego Komitetu Celnego Republiki Abchazji, [online] http://www.customsra.com/-2cqyh, 13 IV 2017.

48 A. Cooley, L.A. Mitchell, Engagement Without Recognition: A New Strategy toward Abkhazia and 
co jakiś czas oświadczenia polityków abchaskich, rozważających możliwość przyznania obywatelom rosyjskim prawa do nabywania nieruchomości na jej terytorium ${ }^{49}$.

Zgodnie z danymi organizacji Freedom House w latach 2009-2015 Federacja Rosyjska przeznaczyła ok. $465 \mathrm{mln}$ dolarów na odbudowę i rozbudowę infrastruktury wojskowej w Abchazji. Ponadto Rosja każdego roku subsydiuje budżet Abchazji kwotą równą ok. 20\% jego wartości, a także przeznacza równowartość ok. 70 mln dolarów na wypłaty emerytur dla mieszkańców Abchazji posiadających obywatelstwo rosyjskie. Do tego należy doliczyć środki przeznaczone na pomoc społeczną oraz różnego rodzaju projekty infrastrukturalne $e^{50}$.

Dalsze pogłębienie wielopłaszczyznowych związków Abchazji i Rosji przyniosło zawarcie w Suchumi w dniu 24 listopada 2014 r. Traktatu o sojuszu i strategicznym partnerstwie Federacji Rosyjskiej i Abchazji. Przewiduje on stworzenie „wspólnej przestrzeni” w sferach obronności, bezpieczeństwa, społecznej, ekonomicznej i kulturowej, zastępując dotychczasową umowę o przyjaźni, współpracy i pomocy wzajemnej z 17 września 2008 r. $^{51}$. Opracowany przez Rosję tekst porozumienia zakłada m.in. szeroki zakres działań ukierunkowanych na dalszą integrację Abchazji z rosyjską gospodarką, w tym dostosowanie prawa celnego do standardów Euroazjatyckiej Unii Gospodarczej ${ }^{52}$. Ponadto rząd Rosji zobowiązał się do przekazania Abchazji subsydiów w wysokości $270 \mathrm{mln}$ dolarów w latach 2015-2017. Bez wątpienia rosyjsko-abchaskie stosunki gospodarcze znajdują się więc w fazie dynamicznego rozwoju, prowadząc do daleko idącej integracji systemu gospodarczego Abchazji z systemem rosyjskim.

Z kolei w całej powojennej historii relacji gruzińsko-abchaskich jedynym przykładem współpracy obu stron konfliktu na płaszczyźnie ekonomicznej stało się ponowne uruchomienie elektrowni wodnej na granicznej rzece Enguri w $2006 \mathrm{r}^{53} \mathrm{~W}$ tym przypadku kooperacja leżała jednak w interesie obu stron, ponieważ zbiornik wodny Enguri położony jest na terytorium Gruzji, zaś sama zapora oraz pozostała infrastruktura na terytorium Abchazji ${ }^{54}$. Należy przy tym podkreślić, że Abchazja ma ograniczone możliwości poszukiwania wsparcia finansowego i ekonomicznego ze strony innych aktorów. Co prawda Unia Europejska i Stany Zjednoczone (w mniejszym stopniu)

Eurasia's Unrecognized States, „The Washington Quarterly” October 2010, s. 65, [online] http://geor gica.tsu.edu.ge/files/05-Security/Cooley\%20\&\%20Mitchell-2010.pdf, 12 III 2017.

49 I. Khasing, Successive Documents between Abkhazia and Russia will Ultimately Breakup the Abkhazian Nationality, „Caucasus Analytical Digest” 2009, nr 7, s. 12, [online] http://www.css.ethz.ch/content/ dam/ethz/special-interest/gess/cis/center-for-securities-studies/pdfs/CAD-7-11-12.pdf, 12 IV 2017. Abkhazia, Freedom House, [online] https://freedomhouse.org/report/freedom-world/2014/abkha zia\#.VdNTbrJViko, 12 IV 2017.

51 M. Falkowski, „Rosyjska Polityka Sąsiedztwa”. Casus Abchazji, Warszawa 2014, [online] http://www.osw. waw.pl/pl/publikacje/analizy/2014-11-26/rosyjska-polityka-sasiedztwa-casus-abchazji, 27 IV 2017.

52 W. Wojtasiewicz, Petzająca aneksja, „Nowa Europa Wschodnia”, [online] https://new.org.pl/2034pelzajaca-aneksja, 27 IV 2017.

53 Dzięki wsparciu finansowemu BŚ oraz EBOiR na tączną kwotę $40 \mathrm{mln}$ dolarów. D. Chkhartishvili, R. Gotsiridze, B. Kitsmarishvili, Georgia. Conflict Regions..., s. 125.

54 È.N. Tužba, Social’no-Èkonomičeskie processy v postvoennoj Abhazii, „Vestnik Upravleniâ” 2012, nr 1 (18), [online] http://vestnik.uapa.ru/ru-ru/issue/2012/01/22/, 14 III 2017. 
zaangażowane są w realizację projektów pomocowych na jej terenie, to jednak ich działalność pozostaje ograniczona do sfery pomocy humanitarnej, wspierania procesu budowy społeczeństwa obywatelskiego oraz tzw. środków budowy zaufania ${ }^{55}$.

W ostatnich latach rząd Abchazji podejmował pewne próby przezwyciężenia trudnej sytuacji społeczno-gospodarczej, wykorzystując zasoby endogeniczne. W 1999 r. opracowany został „Państwowy program rozwoju społeczno-ekonomicznego Republiki Abchazji na lata 2000-2010 - Abchazja w XXI wiek”, ukierunkowany na stworzenie podstaw do rozwoju elastycznej oraz wydajnej społecznej gospodarki rynkowej według odpowiedniego systemu prawnego oraz poprzez budowanie zaufania do państwa $^{56}$. Z kolei w 2005 r. przyjęta została oficjalna „Koncepcja rozwoju społeczno-ekonomicznego Republiki Abchazji", koncentrująca się na wzmocnieniu sektorów energetycznego, rolnego, turystycznego oraz przemysłowego, a także na przyspieszeniu procesu prywatyzacji ${ }^{57}$. Jednakże wobec ograniczonych zasobów finansowych realizacja zawartych w obu dokumentach celów i zadań pozostawała na niezadowalającym poziomie. Aktualnie obowiązująca „Strategia rozwoju społeczno-ekonomicznego Republiki Abchazji do 2025 r." została przyjęta na mocy dekretu de facto prezydenta Abchazji z dnia 3 marca $2016 \mathrm{r}^{58}$. W dokumencie podkreślono, że jednym z najważniejszych celów tej nieuznawanej republiki jest dalszy rozwój wspótpracy pomiędzy Abchazja $i$ Rosją ${ }^{59}$, natomiast realizacja samej Strategii jest uzależniona od efektywnego wykorzystania pomocy finansowej Federacji Rosyjskiej ${ }^{60}$. Oznacza to, że rozwój gospodarczy Abchazji pozostaje w pełni uzależniony od Rosji, czego jej władze są w pełni świadome.

\section{ROZWÓJ GOSPODARCZY ABCHAZJI (JAKO PAŃSTWA NIEUZNAWANEGO) A ROZWÓJ GOSPODARCZY GRUZJI (JAKO PAŃSTWA MACIERZYSTEGO)}

Jak wykazano w niniejszej pracy, trudna sytuacja ekonomiczna nieuznawanej republiki w okresie powojennym wiązana jest z brakiem uznania międzynarodowego oraz reżimem izolacji międzynarodowej, nałożonej na Abchazję w 1996 r. i utożsamianej powszechnie z oboma państwami sąsiedzkimi, tj. Gruzją i Rosją. Stopniowe łagodzenie

55 Conflict Resolution in the South Caucasus: The EU's Role, International Crisis Group Europe Report $N^{\circ} 173$ - 20 March 2006, s. 16, [online] https://www.crisisgroup.org/europe-central-asia/caucasus/ conflict-resolution-south-caucasus-eu-s-role, 12 IV 2017.

56 Abhaziâ - vXXI vek. Gosudarstvennaâ programma social'no èkonomičeskogo razvitiâ Respubliki Abhaziâ na 2000-2010 gg., [online] http://www.filesofcoffee.narod.ru/OFFICIAL/programm.html, 14 IV 2017.

57 Koncepciâ social’no-èkonomičeskogo razvitiâ Respubliki Abhaziâ, „Kavkazskij Uzel” 27 VII 2006, [online] http://www.kavkaz-uzel.ru/articles/100306/, 14 IV 2017.

58 Ukaz „Ob utverždenii Strategii social'no-èkonomičeskogo razvitiâ Respubliki Abhaziâ do 2025 goda”, [online] http://presidentofabkhazia.org/about/info/news/?ELEMENT_ID=3661, 12 IV 2017.

59 Strategiâ social’no-èkonomičeskogo razvitiâ Respubliki Abhaziâ do 2025 g., s. 255, [online] http://ru.ab khaziastrategic.org/, 12 IV 2017.

60 Tamże, s. 261. 
reżimu sankcji od 1999 r. oraz jednostronne uznanie abchaskiej niepodległości przez Rosję sprawiło, że poprawa sytuacji społeczno-gospodarczej w Abchazji zaczęła być bezpośrednio wiązana z pomocą rosyjską, a jej przyszły rozwój - z kontynuacją współpracy bilateralnej. Z kolei brak kontaktów gospodarczych oraz wymiany informacji pomiędzy Gruzją i Abchazją doprowadził do daleko idącego odseparowania społeczeństw obu stron konfliktu, stając się przyczyną nie tylko braku szerszego zainteresowania przemianami społeczno-gospodarczymi w Gruzji, ale również powstania szeregu mitów na temat południowo-wschodniego sąsiada. $Z$ wyników badań przeprowadzonych przez Johna O'Loughlina, Vladimira Kolossova i Gerarda Toala wynika, że pomimo obserwowanego od początku XXI w. dynamicznego rozwoju gospodarczego Gruzji większa część społeczeństwa abchaskiego uważa, iż poziom życia w Gruzji oraz jej sytuacja gospodarcza przedstawia się obecnie znacznie gorzej niż w Abchazji ${ }^{61}$. Wszystko to sprawia, że Abchazowie nie postrzegają Gruzji nawet jako potencjalnego partnera gospodarczego, co w obecnej sytuacji dodatkowo zmniejsza ich skłonność do działań na rzecz uregulowania konfliktu.

Rys. 1. PKB per capita w Gruzji i Abchazji w latach 1989-2015

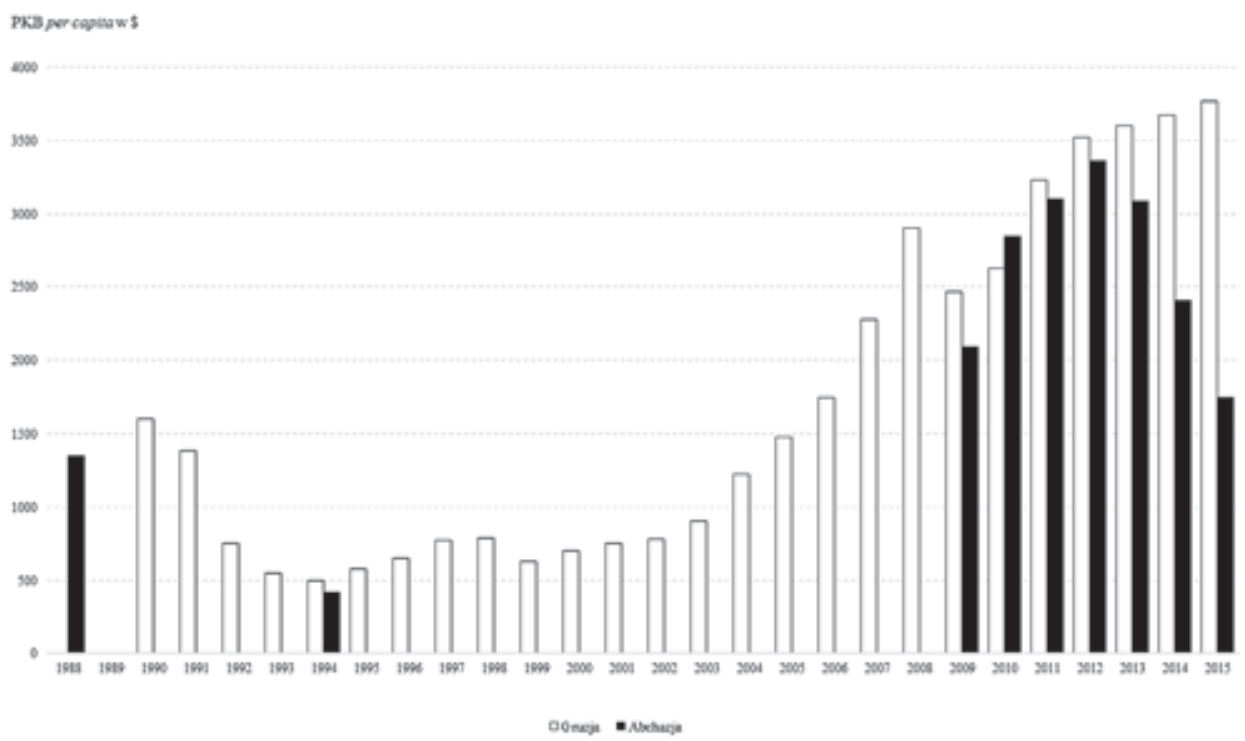

Źródło: opracowanie własne na podstawie: danych Państwowego Biura Statystyki Gruzji Geostat (www. geostat.ge, 10 V 2017) oraz Państwowego Urzędu Statystycznego Republiki Abchazji (http://ugsra.org/, 10 V 2017). Przeliczeń dokonano na podstawie oficjalnego kursu rubla oraz lari w stosunku do dolara amerykańskiego według danych Banku Światowego: http://data.worldbank.org/indicator/PA.NUS.FCRF, 13 III 2017. Dane nt. PKB Abchazji gromadzone są w trybie ciągłym dopiero od 2009 r.

61 J. O'Loughlin, V. Kolossov, G. Toal, Inside Abkhazia - A Survey of Attitudes in a De Facto State, „Post-Soviet Affairs” 2011, vol. 27, nr 1, s. 20, [online] http://www.tandfonline.com/doi/ abs/10.2747/1060-586X.27.1.1, 12 IV 2017. 
W tym kontekście warto porównać dynamikę oraz wysokość produktu krajowego brutto na jednego mieszkańca (będącego podstawowym miernikiem poziomu rozwoju gospodarczego) dla Abchazji oraz jej tzw. państwa macierzystego, tj. Gruzji (rys. 1). W momencie zakończenia wojny gruzińsko-abchaskiej w 1994 r. wartość analizowanego wskaźnika dla obu stron konfliktu pozostawała na względnie zbliżonym, bardzo niskim poziomie i wynosiła 517 dolarów w przypadku Gruzji oraz 410 dolarów - Abchazji. W kolejnych latach (1995-2003) gospodarka Gruzji pogrążona była w głębokim, wielopłaszczyznowym kryzysie. W tym okresie wartość PKB per capita utrzymywała się na niskim poziomie, zawierając się w przedziale 500-800 dolarów. Począwszy od 2004 r. (dojście do władzy prezydenta Micheila Saakaszwilego), w Gruzji doszło do wyraźnego ożywienia gospodarczego, odzwierciedlanego ponaddwukrotnym wzrostem wartości analizowanego wskaźnika w latach 2004-2008. Bazując na danych dotyczących nakładów inwestycyjnych, obrotów w handlu wewnętrznym i zagranicznym, a także produkcji rolnej i przemysłowej, można wnioskować, że w tym okresie doszło również do nieznacznej poprawy sytuacji gospodarczej w Abchazji, będącej konsekwencją stopniowego łagodzenia reżimu sankcji oraz wzrostu zaangażowania kapitału rosyjskiego. Kolejny impuls do rozwoju gospodarczego Abchazji przyniosło jednostronne uznanie niepodległości Abchazji przez Rosję w sierpniu 2008 r., za czym podążyło wielomilionowe wsparcie finansowe przeznaczone na odbudowę abchaskiej gospodarki. Przemiany te doprowadzily do wzrostu poziomu PKB per capita Abchazji w cenach bieżących w latach 2009-2011 o prawie 50\%, dzięki czemu w 2011 r. wartość tego wskaźnika ukształtowała się na poziomie zbliżonym do gruzińskiego, a w $2010 \mathrm{r}$. nawet nieznacznie go przekroczyła. Deprecjacja rubla w ciągu ostatnich trzech lat wpłynęła co prawda na wyraźny spadek wartości PKB per capita Abchazji wyrażonego w dolarach, który w 2015 r. stanowił zaledwie połowę wartości analogicznego wskaźnika dla Gruzji. Jednakże biorąc pod uwagę brak szerszych powiązań gospodarczych ze środowiskiem międzynarodowym (poza Federacją Rosyjską oraz Turcją), zmiana ta nie jest przez mieszkańców Abchazji odczuwana, zwłaszcza że skumulowany wzrost PKB w latach 2012-2015 wyniósł 27,6\%.

\section{ZAKOŃCZENIE}

Wojna gruzińsko-abchaska z lat 1992-1993 doprowadziła do uzyskania przez Abchazję de facto niepodległości. Od tego momentu Abchazja nie była jednak w stanie rozwinąć efektywnego systemu gospodarczego, na co złożyło się co najmniej kilka przyczyn. Po pierwsze, o trudnej sytuacji gospodarczej w Abchazji przesądziły bezpośrednie skutki działań wojennych, obejmujące zniszczenia w sferze infrastrukturalnej, załamanie produkcji przemysłowej i produkcji rolnej oraz depopulację kraju. Po drugie, od momentu uzyskania de facto niepodległości w 1994 r. system gospodarczy Abchazji funkcjonuje w warunkach braku, a od 2008 r. - częściowego braku uznania międzynarodowego, co istotnie ograniczało i ogranicza jego możliwości rozwojowe. Obserwowane w przypadku Abchazji tzw. ekonomiczne koszty braku uznania 
międzynarodowego przejawiają się m.in. w braku dostępu do zewnętrznych źródeł finansowania, w tym dostępu do kredytów zagranicznych, oraz w trudnościach związanych z przyciąganiem bezpośrednich inwestycji zagranicznych wobec braku międzynarodowych gwarancji, a także obaw inwestorów o możliwość utracenia znacznie większego rynku gruzińskiego ${ }^{62}$. Trzecim czynnikiem hamującym rozwój gospodarczy powojennej, de facto niepodległej Abchazji, stała się jej izolacja (obejmująca przede wszystkim ograniczenia w handlu zagranicznym), narzucona na tę nieuznawaną republikę przez środowisko międzynarodowe. W wyniku nałożonej blokady gospodarka Abchazji w okresie powojennym nie była w stanie podjąć wysiłku związanego z odbudową i rozwojem, pogrążając się w długotrwałym kryzysie gospodarczym. Uniemożliwiła ona również odbudowę zerwanych powiązań handlowych oraz powrót do tradycyjnych rynków zbytu, utraconych wraz z rozpadem ZSRR i upadkiem systemu komunistycznego. Izolacja przyczyniła się również do rozwoju nielegalnego biznesu i szarej strefy, wynikających przede wszystkim z braku możliwości prowadzenia legalnego handlu z zagranicą. Z kolei czwartym czynnikiem determinującym kondycję gospodarki Abchazji stała się słabość struktur państwowych, niezdolnych do wdrażania reform ekonomicznych oraz podejmowania skutecznych inicjatyw służących odbudowie kraju i stymulacji procesów rozwojowych, przede wszystkim ze względu na szczupłość dostępnych środków budżetowych.

Abchazja pozostawała niemal w pełni izolowana do 1999 r., kiedy to reżim sankcji zaczął ulegać stopniowemu łagodzeniu przez Federację Rosyjską. W 2008 r. Rosja uznała niepodległość Abchazji, która zgodziła się na przekazanie wielu atrybutów własnej suwerenności, w tym w sferze ekonomicznej, w zamian za rosyjską pomoc finansową. Obecnie rosyjsko-abchaskie stosunki gospodarcze znajdują się w fazie dynamicznego rozwoju, prowadząc do daleko idącej integracji abchaskiego systemu gospodarczego z systemem rosyjskim. W konsekwencji Abchazja pozostaje w pełni uzależniona ekonomicznie od swojego północnego sąsiada. Biorąc pod uwagę powyższe przemiany, aktualnie politykę izolacji gospodarczej względem Abchazji realizowaną przez Gruzję i państwa Zachodu można uznać za kontrproduktywną, prowadzi ona bowiem jedynie do dalszego pogłębiania ekonomicznej zależności Abchazji od Rosji.

\section{BIBLIOGRAFIA}

Abhaziâ v cifrah 2011, Suhumi 2012.

Abhaziâ v cifrah 2014, Suhumi 2015.

Abhaziâ v cifrah 2015, Suhumi 2016.

Abhaziâ - v XXI vek. Gosudarstvennaâ programma socialno èkonomičeskogo razvitiâ Respu-

bliki Abhaziâ na 2000-2010 gg., [online] http://www.filesofcoffee.narod.ru/OFFICIAL/ programm.html.

62 P. Kolstø, The Sustainability and Future of Unrecognized Quasi-States, „Journal of Peace Research” 2006, vol. 43, nr 6, s. 729, [online] https://doi.org/10.1177/0022343306068102. 
Abkhazia: Deepening Dependence, International Crisis Group Europe Report $N^{\circ} 202-26$ February 2010, [online] https://www.crisisgroup.org/europe-central-asia/caucasus/georgia/ abkhazia-deepening-dependence.

Abkhazia. Old and Frail In the Shadow of the Embargo. Report, Médecins Sans Frontiérs, December 2002, [online] https://www.msf.fr/sites/default/files/7083212723e4147d15960a laa0b48d44.pdf.

Abkhazia: Ways Forward, International Crisis Group Europe Report $N^{\circ} 179$ - 18 January 2007, [online] https://www.crisisgroup.org/europe-central-asia/caucasus/abkhazia-georgia/abkhaziaways-forward.

Akaba N., Inar G., Izolâciâ/deizolâciâ Abhazii i transformaciâ gruzino-abhazskogo konflikta. Istoriko-političeskij analiz, [w:] Deizolaciâ Abhazii, London 2011, [online] http://legacy. international-alert.org/sites/default/files/publications/201104DeisolationAbkhaziaRU.pdf.

Bank Światowy, [online] http://data.world-bank.org/indicator/PA.NUS.FCRF.

Bargandzhia D., Economy: Traditional and Modern, [w:] The Abkhazians. A Handbook, red. G. Hewitt, London-New York 1998.

Chirikba V., Abkhazia - Economic and Political Situation and Perspectives, [online] http://www. kapba.de/EconAndPolSit.html.

Chkhartishvili D., Gotsiridze R., Kitsmarishvili B., Georgia. Conflict Regions and Economies, [w:] From War Economies to Peace Economies in the South Caucasus, red. Ph. Champain, D. Klein, N. Mirimanova, London 2011.

Closson S., Georgia's Secessionist De Facto States: From Frozen to Boiling, „Caucasus Analytical Digest” 2008, nr 40, [online] http://www.css.ethz.ch/content/dam/ethz/special-interest/ gess/cis/-center-for-securities-studies/pdfs/RAD-40-2-5.pdf.

Conflict Resolution in the South Caucasus: The EU's Role, International Crisis Group Europe Report $N^{\circ} 173$ - 20 March 2006, [online] https://www.crisisgroup.org/europe-central-asia/ caucasus/conflict-resolution-south-caucasus-eu-s-role.

Cooley A., Mitchell L.A., Engagement Without Recognition: A New Strategy toward Abkhazia and Eurasia's Unrecognized States, „The Washington Quarterly” 2010, vol. 33, nr 4, [online] https://doi.org/10.1080/0163660X.2010.516183.

Curtis G.E., Involvement of Russian Organized Crime Syndicates, Criminal Elements in the Russian Military, and Regional Terrorist Groups in Narcotics Trafficking in Central Asia, The Caucasus and Chechnya, Washington 2002, [online] https://www.loc.gov/rr/frd/pdf-files/ RussianOrgCrime.pdf.

Dogovor o družbe, sotrudničestve i vzaimnoj pomoŝi meždu Rossijskoj Federaciej i Respublikoj Abhaziâ ot 17 sentâbrâ 2008 g., [online] http://archive.kremlin.ru/text/docs/2008/09/206583.shtml.

Ezrow N.M., People without Passports - Exploring the Consequences of Different Types of Restricted Mobility, Paper prepared for the annual meetings of the Midwest Political Science Association, Chicago, 2-6 April 2008, [online] http://citation.allacademic.com/meta/p_mla_ apa_research_citation/-2/6/8/4/3/pages 268437/p268437-1.php.

Falkowski M., „Rosyjska Polityka Sąiedztwa”. Casus Abchazji, Warszawa 2014, [online] http://www. osw.waw.pl/pl/publikacje/analizy/2014-11-26/rosyjska-polityka-sasiedztwa-casus-abchazji. Federal'nyj zakon o graždanstve Rossijskoj Federacii ot 31 maâ 2002 g., H62-63, [online] http:// www.mid.ru/-dks.nsf/mnsdoc/04.03.02.02. 
Gegeshidze A., The Isolation of Abkhazia. a Failed Policy or an Opportunity, [w:] Accord. Powers of persuasion. Incentives, sanctions and conditionality in peacemaking, red. A. Griffiths, C. Barnes, London 2008, [online] http://www.cr.org/sites/cr.org/files/19_Powers\%20 of\%20persuasion_2008_ENG_F.pdf.

Gegešidze A., Vvedenie, [w:] Deizolaciâ Abhazii, London 2011, [online] http://legacy.inter national-alert.org/sites/default/files/publications/201104DeisolationAbkhaziaRU.pdf.

Gomelauri T., The Role of Economic Factors in Conflict Resolution in Georgia and the Caucasus, Budapest 2001/2002, [online] http://pdc.ceu.hu/archive/00001807/.

Gosduma RF odobrila soglašeniâ o bespošlinnoj torgovle s abhaziej i ûžnoj osetiej, „Kavkazskij Uzel” 10 X 2013, [online] https://www.kavkaz-uzel.ru/articles/234889/.

Gumba Y., Ketsba T., Economic development prospects in Abkhazia and the concept of regional cooperation, [w:] From War Economies to Peace Economies in the South Caucasus, red. Ph. Champain, D. Klein, N. Mirimanova, London 2011.

Khasing I., Successive Documents between Abkhazia and Russia Will Ultimately Breakup the Abkhazian Nationality, „Caucasus Analytical Digest” 2009, nr 7, [online] http://www.css. ethz.ch/content/dam/ethz/special-interest/gess/cis/center-for-securities-studies/pdfs/ CAD-7-11-12.pdf.

Koèn D., Ekkonomičeskie aspekty. Stimul ili prepâtstvie?, [w:] Problemy suvereniteta. Gruzino-abhazskij process mirnogo uregulirovaniâ, red. D. Koèn, London 1999, [online] http:// www.c-r.org/sites/c-r.org/files/Accord7_RussianFull.pdf.

Kolstø P., The Sustainability and Future of Unrecognized Quasi-States, „Journal of Peace Research" 2006, vol. 43, nr 6, [online] http://journals.sagepub.com/doi/abs/10.1177/ 0022343306068102 , https://doi.org/10.1177/0022343306068102.

Koncepciâ social’no-èkonomičeskogo razvitiâ Respubliki Abhaziâ, „Kavkazskij Uzel” 2006, 27 VII, [online] http://www.kavkaz-uzel.ru/articles/100306/.

Konflikty v Abhazii i Û̌nnoj Osetii. Dokumenty 1989-2006 gg., red. M. Volhonskij, V. Zaharov, N. Silaev, Moskva 1997.

Krylov A., Religiâ i tradicii Abhazov (po materialam polevyh issledovanij 1994-2000 gg.), Moskva 2001.

Kukhianidze A., Kupatadze A., Gotsiridze R., Smuggling through Abkhazia and Tskhinvali Region, Tbilisi 2004.

O vyâvlennyh faktah politiki ètničeskoj čistki/genocida, provodimoj na teritorii Abhazii, Gruziâ, i neobhodimosti peredači vinovnyh lic $v$ ruki pravosudiâ v sootvetsvii s meždunarodnymi principami nadležâ̂̀̂̀ego sudebnogo processa. Zaklûcenie Gosudarstvennoj Komisii Gruzii po ustanovleniû faktov politiki ètničeskoj čistki-genocida, provodimoj v otnošenii gruzinskogo naseleniâ v Abhazii, Gruziâ, i peredači materialov v Meždunarodnyj Tribunal, Moskva 1997.

OCHA Georgia: Abkhazia Briefing Note, United Nations Development Programme (UNDP) 2004, [online] http://reliefweb.int/report/georgia/ocha-georgia-abkhazia-briefing-note-jan-2004.

O'Loughlin J., Kolossov V., Toal G., Inside Abkhazia - A Survey of Attitudes in a De Facto State, „Post-Soviet Affairs” 2011, vol. 27, nr 1, [online] http://www.tandfonline.com/doi/ abs/10.2747/1060-586X.27.1.1, doi: 10.2747/1060-586X.27.1.

Otčet o rezul'tatah kontrol'nogo meropriâtiâ «Proverka celevogo i éffektivnogo ispol'zovaniâ sredstv federal’nogo bûdžeta, napravlennyh na okazanie finansovoj pomosi i Respublike Abhaziâ v celâh 
social'no-èkonomičeskogo razvitiâ i osuŝestvleniâ bûdžetnyh investicij», [online] http://www. ach.gov.ru/userfiles/bulletins/2012-07-06-buleten_doc_files-fl-2247.pdf.

Państwowy Komitet Celny Republiki Abchazji, [online] http://customsra.org/customs_ statistics_of_foreign_trade/.

Postanovlenie Pravitel'stva Rossijskoj Federacii ot 19 dekabrâ 1994 g. N 1396 o merah po vremennomu ograničeniû peresečeniâ Gosudarstvennoj granicy Rossijskoj Federacii s Azerbajdžanskoj Respublikoj i Respublikoj Gruziâ, [online] http://pravo.gov.ru/proxy/ips/?doc_ itself $=\&$ backlink $=1 \& \&$ nd $=102033244 \& \&$ page $=1 \& \mathrm{rdk}=9$.

Report of UNDP-Led Feasibility Mission to Gali District and Adjacent Areas of Abkhazia, and Georgia, Bureau for Crisis Prevention and Recovery 2004.

Resolution 876 (1993) Adopted by the Security Council at its 3295th meeting, on 19 October 1993, [online] http://www.refworld.org/docid/3b00f15a50.html.

Strategiâ social'no-èkonomičeskogo razvitiâ Respubliki Abhaziâ do 2025 g., [online] http://ru.ab khaziastrategic.org/.

Svendsen I.Ch., Prospects for Return of Internally Displaced Persons (IDPs) to Abkhazia in Georgia, Tbilisi 2005, [online] http://www.internal-displacement.org//\$file/Abkhazia+NR$\mathrm{C}+\mathrm{Nov}+05 . \mathrm{pdf}$.

Tokmazishvili M., Money Laundering and Money Corporation Relations in Abkhazia, [online] http://www.conflicts.rem33.com/images/Georgia/crim_abkh_tokmaz.pdf.

Traughber C.M., Terrorism and Arms, Drug, and Human Trafficking in Georgia, „The Quarterly Journal", Spring 2007, [online] http://connections-qj.org/system/files/06.1.04_traughber. pdf.

Trier T., Lohm H., Szakonyi D., Under Siege. Inter-Ethnic Relations in Abkhazia, London 2010. Tužba Ė.N., Social'no-Ėkonomičeskie processy v postvoennoj abhazii, „Vestnik Upravleniâ” 2012, nr 1 (18), [online] http://vestnik.uapa.ru/ru/issue/2012/01/22/.

Ukaz „Ob utverždenii Strategii social'no-èkonomičeskogo razvitiâ Respubliki Abhaziâ do 2025 goda", [online] http://presidentofabkhazia.org/about/info/news/?ELEMENT_ID=3661. UNDP/World Bank Needs Assessment. Mission to Abkhazia, Georgia, February/March 1998, [online] http://www.berntbernander.com/PDF/reports/Abkhasia.pdf.

Wojtasiewicz W., Petzająca aneksja, „Nowa Europa Wschodnia”, [online] https://new.org. $\mathrm{pl} / 2034$-pelzajaca-aneksja.

V Abhazii zaregistrirovany 26 tysấr rossijskih pensionerov, „Naselenie i Obŝestvo” 2005, nr 197-198, [online] http://www.demoscope.ru/weekly/2005/0197/panorm01.php\#1.

Andrzej JAKUBOWSKI - dr nauk społecznych w zakresie nauk o polityce, adiunkt w Zakładzie Geografii Społeczno-Ekonomicznej na Wydziale Nauk o Ziemi i Gospodarki Przestrzennej Uniwersytetu Marii Curie-Skłodowskiej w Lublinie. Zainteresowania badawcze: konflikty etnopolityczne, przemiany demograficzne i narodowościowe, obszary przygraniczne i transgraniczne. 